\title{
Elementary Content Teacher Perceptions Regarding Their ELL Instructional Practices
}

\author{
C. Wesley Owens, EdD \\ Walden University, Minneapolis, Minnesota, United States \\ (iD) https://orcid.org/0000-0002-4405-8453 \\ Steve P. Wells, EdD \\ Walden University, Minneapolis, Minnesota, United States
}

Contact: cwes.owens@yahoo.com

\section{Abstract}

The purpose of this qualitative descriptive study was to explore the instructional practices of elementary English language learner (ELL) teachers and how those practices are perceived by the teachers to be aligned with improved ELL academic performance. The study is grounded in Ladson-Billings' theory of culturally relevant pedagogy, which holds that student academic achievement and cultural identity should be affirmed. The research questions focused on exploring instructional practices used by teachers to support ELL learning and the teachers' perceptions of how their practices are aligned with improved ELL academic performance. The qualitative descriptive study was limited to three elementary schools in an Eastern school district. We analyzed data from lesson plans and semistructured interviews with nine general education teachers who taught in an elementary school in the geographical area. Using a priori, open, and axial coding, we analyzed data from lesson plans and semi-structured interviews with nine elementary school general education teachers who taught in a school in the geographical area. The findings demonstrated that positive strategies for cooperative learning and varied instructional practices were in use, but there is a need to build culturally appropriate and collaborative relationships with teachers of speakers of other languages and create a welcoming learning atmosphere for ELLs. A policy recommendation paper was developed to improve ELL pedagogy in content classes. Improved instruction for ELLs will contribute to positive social change by increasing ELL students' academic achievement.

Keywords: English language learner; culturally relevant pedagogy; instructional practices; culturally relevant instruction; academic achievement

Date Submitted: September 10, 2020 | Date Published: May 21, 2021

\section{Recommended Citation}

Owens, C. W., \& Wells, S. P. (2021). Elementary content teacher perceptions regarding their ELL instructional practices. Journal of Educational Research and Practice, 11, 139-152. https://doi.org/10.5590/JERAP.2020.11.1.10

\section{Introduction}

As student populations in public schools become increasingly diverse and the achievement gap between English language learners (ELLs) and English-speaking students continues to grow, researchers, lawmakers, 
and school district personnel seek ways to increase ELL academic performance. Federal laws and initiatives, such as Race to the Top (U. S. Department of Education [USDOE], 2009) and Every Student Succeeds Act (ESSA, USDOE, 2015), were intended to close the performance gap between ELL and non-ELL students, but ELLs continue to score significantly lower than non-ELLs in reading and math at the fourth-grade level (NAEP, 2019). This persistent performance gap and the increasing number of ELLs in public school classrooms (USDOE, 2019) have sparked improvement efforts in the field of ELL instruction (Castro-Olivo et al., 2018).

\section{Problem Statement}

The problem addressed in this study, which took place in a metropolitan Virginia school district, is the need to explore the instructional practices of elementary content teachers of ELLs and how those practices are perceived by the teachers to be aligned with improved ELL academic performance. The setting for this study was three elementary schools in the district, which includes more than 90 elementary, middle, and high schools. The three schools average more than 30 content teachers; each school has one principal and one assistant principal and an average class size of 25. Leaders in the local district are charged with the task of meeting and exceeding state standards while helping ELLs become proficient in English. On-time graduation rates in this Virginia school district exceed state averages overall (92\%), but ELLs comprise the lowest on-time graduation rates (82\%) of all student groups (VDOE, 2018). In the local setting, it is important to understand how content teachers use research-based ELL instructional strategies because such approaches are linked to improved ELL academic performance (Turkan \& Burzick, 2016).

\section{Gap in the Literature}

A disparity exists between ELLs and other ethnic subgroups in student performance and socioeconomic status. Carnoy and Garciá (2017) noted that academic performance in Black and Hispanic students has improved, causing a decrease in the gap in performance between these two groups and other nonethnic students. The difference in academic performance between ELLs and nonethnic subgroups, however, remained unchanged. Asian and Hispanic ELLs are falling behind White students (Carnoy \& Garciá, 2017). Socioeconomic disparities also exist because ELLs are more likely to have a higher rate of poverty than European American, African American, Asian American, and Hispanic American non-ELLs. Low socioeconomic status correlates significantly with lower academic achievement (Barragan et al., 2018; Gay, 2013). The achievement gaps and socioeconomic disparities, then, support the need for this study.

Elementary teachers of ELLs face the dual challenge of promoting academic achievement across subject areas and teaching English language and literacy to a mixed group, some of whom can speak English and some of whom cannot (Kim, 2017). According to Diaz et al. (2016), some content teachers have low expectations for ELLs. Often, they hesitate to acknowledge that high academic performance can even be expected before ELLs develop English skills (Diaz et al., 2016). Teachers who favor a less rigorous curriculum for ELL students run the risk of contributing to the achievement gap between ELLs and non-ELL learners (Murphy \& Torff, 2019). Therefore, it is necessary to address content teachers' uncertainty about how to improve instructional practice for ELLs.

\section{Significance}

The findings of this study are significant as they can help teachers gain an understanding of the instructional practices that are applied with the intention of improving the academic performance of ELLs. According to O'Brien and Leighton (2015), knowledge of instructional methods is needed to identify ways to strengthen ELL conceptual knowledge and academic achievement. A better understanding of instructional practice alignment with research-based practices provides greater insight when educating teachers who have ELLs in their classroom (Feiman-Neimser, 2018) and may provide teachers with insights into how to improve ELLs' 
academic performance (Grasparil \& Hernandez, 2015). Increasing teachers' understanding of instructional practices for ELLs provides students with better opportunities to succeed academically.

\section{Research Questions}

RQ 1: What instructional practices do elementary content teachers say they use to support ELL learning?

RQ 2: What practices are perceived to be aligned with improved ELL academic performance?

\section{Literature Review}

This literature review begins with a discussion of the conceptual framework used to guide this study, including a description of the constructs of culturally relevant instruction, and the benefits of integrating it into the classroom. Following the conceptual framework is a comprehensive review of research related to (a) culturally relevant curriculum (CRC), (b) effective instructional practices for ELLs, and (c) teachers' beliefs about ELL instruction. These subtopics provide an explanation of the research problem.

\section{Conceptual Framework}

The theory of culturally relevant pedagogy (CRP; Ladson-Billings, 1994, 1995, 2006) is rooted in the theoretical tenets of Vygotsky's philosophy of social and cognitive construction that originated in the 1990s from research on educational inequity of ethnically diverse students. Fundamental to this basic understanding is the Vygotskian explanation for the cultural shifts occurring among the children in today's classrooms. Vygotsky (1978) recognized the importance of how cultural, social, and historical factors have an impact on students' thinking and learning. Vygotsky noted that individuals construct knowledge based on their prior learning experiences. Guided by the instruction of their teachers, students can be proficient learners when educational experiences relate to their cultures.

CRP informs the framework for the research design components of this study. According to Ladson-Billings (1995),

culturally relevant pedagogy rests on three criteria or propositions; (a) Students must experience academic success; (b) students must develop and/or maintain cultural competence, and; (c) students must develop a critical consciousness through with they challenge the status quo of the current social order. (p. 160)

Davis and McCarther (2015) asserted that teachers who use CRP discover effective instructional practices that acknowledge students' cultural backgrounds in the identified learning style of students. CRP involves instructional practices that draw on students' cultural and linguistic strengths, which enable students to reach higher levels of academic success (Powell et al., 2016). CRP can be a useful practice that empowers teachers to see culture as an asset to enrich students' social and academic achievement.

\section{Culturally Relevant Curriculum}

When the curriculum is meaningful and the instruction matches their cultural background, students' performance improves. DeCapua (2016) found that teachers can reduce cultural differences by building on the cultural experience of students to enhance their performance. Meaningful and matching achievements and familiar referents of ELLs are essential characteristics of a CRC (Dong, 2017). Familiar referents, according to Dong, include instructional materials that mirror ELL home culture and life experiences. A CRC goes beyond the biographies of notable historical figures and infuses content with meaning for ELLs (DeCapua \& Marshall, 2015). A CRC can engage ELLs using their cultural and experiential knowledge in the classroom (Jaffe, 2016). 
According to Samuels (2018), learning about the lives of students helps teachers promote culturally relevant teaching by making applicable connections between curriculum materials and students' cultural experiences. Viewing learning from the students' perspective creates social relationships and a sense of community, which further strengthens the union between the teacher and student (Ragoonaden \& Mueller, 2017). In essence, when students make sense of their world, they respond better by using prior knowledge, past experiences, and cultural references.

\section{Effective Instructional Practices for ELLs}

Gomez and Diarrassouba (2014) conducted a study of the perceptions of elementary teachers who taught culturally and linguistically diverse students and found that teachers were not adequately prepared to teach ELLs. Even when prepared to teach in a culturally diverse classroom, teachers lacked sufficient cultural knowledge to implement instructional practices that were suitable for ELLs. Pappamihiel and Lynn (2016) studied ELL teachers who were asked their perceptions concerning instructional and linguistic accommodations needed to support ELL academic performance and discovered that many of the participants were not comfortable implementing the adjustments. The researchers concluded that mainstream teachers need to be better equipped to implement adequate linguistic and instructional accommodations to improve the academic performance of ELLs in the classroom.

According to Grasparil and Hernandez (2015), high dropout rates among ELLs were attributed to poor literacy achievement. The researchers found that implementing effective reading instructional practices may enhance literacy among ELLs. Grasparil and Hernandez revealed that a mismatch between a widely used reading program component and ELL instructional needs accounted for poor literacy performance. The authors concluded that effective instructional strategies for ELLs should include verbal reading articulacy, phonemic cognizance, language, phonics, and comprehension. Research-based instructional practices may increase the graduation and literacy performance among linguistically challenged students.

\section{Teachers' Beliefs About ELL Instruction}

ELL educational experiences can be positively or negatively shaped by a teacher's beliefs and instructional approaches. Murphy and Torff (2019) found that many content teachers favored a less rigorous curriculum for ELLs than non-ELLs. A less rigorous curriculum, according to the authors, may contribute to the academic achievement gap between ELLs and non-ELL students. For ELLs to receive an equitable education, educators need to develop effective instructional strategies that target teachers' beliefs about ELL potential. de Araujo (2017) examined how teachers' beliefs affected their selection of tasks based on the linguistic and mathematical abilities of ELLs and found that teacher beliefs and practices should be critically explored to counter negative educational experiences of ELLs. The tasks teachers select, based on their beliefs about their students, may impact ELLs' academic performance. Further, Clark-Goff and Eslami (2016) found that teacher beliefs can be altered to overcome misconceptions regarding ELLs. Uncovering teachers' beliefs concerning ELLs can be crucial if those beliefs translate to teachers having lower performance expectations for ELLs.

\section{Method}

We used a qualitative descriptive study to explore the instructional practices of elementary content teachers of ELLs and investigate how those practices are perceived by the teachers to be aligned with improved academic performance (Caelli et al., 2003). A qualitative descriptive study provided an enhanced understanding of pedagogical strategies that content teachers use to teach ELLs in mainstream classrooms. This is because the qualitative descriptive study can be used to obtain in-depth and creditable information from participants using qualitative data collection, such as semistructured interviews and document analysis (Yin, 2014). The study brought an understanding of the phenomenon of elementary content teachers' instructional practices of ELLs. 


\section{Participant Selection}

This study was made possible through a partnership agreement between Walden University and the local school district. The participants selected for this qualitative study included content elementary teachers from three elementary schools located in the U.S. mid-Atlantic region who, at some point in their teaching careers, had ELL students in their classrooms. We used purposeful sampling to select participants who (a) were regular elementary content teachers and (b) had ELLs in their classroom at some point in their tenure. After obtaining approval from the district administration and the Walden University IRB, we received the consent of nine teachers to participate in the study. The researchers had no relationship with any of the participants before the data collection.

\section{Data Collection}

Data collection procedures included the use of semistructured interviews and analysis of lesson plans. Each semistructured interview was audio-recorded and conducted outside of school hours in a setting selected by the teacher for privacy. The careful use of reflective questioning allowed for accurate data collection during the interviews. To ensure the validity of the questionnaire, we submitted the interview protocol to a panel of experts for review. All members of the panel were qualitative experts with more than 15 years of experience. The interviews were transcribed within 24 hours of each session and provided full and in-depth responses from the teachers regarding their own instructional practices (Creswell \& Creswell, 2014; Kvale, 2008; Merriam, 2015).

Once the interview process was completed, participants were asked to provide copies of their weekly lesson plans. Lesson plans were only collected from teachers who currently had ELLs in their classrooms. The data from the lesson plans provided a recurrent view of the objectives of lessons taught to ELLs by the participants. A review of the lesson plan documents was also conducted to triangulate the findings from interviews (Hatch, 2002). The lesson plans were coded with the use of the Frequency of Instructional Methods (Lopez \& Mason, 2017), developed to identify types of instructional methods utilized by school personnel. According to Glesne (2011), lesson plans can be used to authenticate the instructional practices that teachers use to support ELL learning. Lesson plans, according to Castro (2015), can also identify the needs of ELLs based on their academic strengths and challenges. Lesson plans reflect the way teachers adopt instructional materials and how learning theory is translated into practice (Choy et al., 2013).

\section{Data Analysis Plan}

During the first stage of data analysis, all interview transcripts were read repeatedly to become familiar with the data. A priori codes based on the conceptual framework were listed in the codebook. The a priori codes consisted of the constructs of CRP: (a) academic success, (b) cultural competence, and (c) development of sociopolitical consciousness (Ladson-Billings, 1995, p. 160). During the second stage of data analysis, initial impressions and open codes were recorded. Codes were organized as either a priori or open by colored highlights, and copious notes were made in the margins of the transcriptions to aid in interpretation (Lodico et al., 2010). The highlighted material was logged into an Excel spreadsheet, which allowed for easy comparison of the coded data by participant, school, and grade level.

In the third stage of data analysis, categories of meaning emerged from the data (Cho \& Lee, 2014; Creswell \& Creswell, 2014). A priori codes were compared with the open codes formulated from the data onto separate spreadsheets to explore connections in the data (Merriam, 2009). This was done to address the research questions by providing a picture of what instructional practices, from the perspective of the teachers, connect with the improved ELL academic performance. Four major themes emerged from the data: issues related to (a) cooperative learning strategies, (b) varied instructional strategies, (c) collaboration with ESOL teachers, and (d) a welcoming learning environment. 


\section{Trustworthiness}

Member checking improved the trustworthiness of the findings. A system of member checking took place during each interview, where the information was restated and summarized to check for accuracy from each participant (Merriam, 2009). By restating and summarizing participants' interview information, we found no contradiction of statements. After the interviews were transcribed, each interview was sent via e-mail to the participants to ensure that their responses were not prejudiced by researcher biases (Lodico et al., 2010). Participants were able to make suggestions to ensure that their perspectives were fully captured during the member checking process (Merriam, 2015). Of the nine participants, only one teacher made revisions to their transcripts, and those revisions were added. Member checking provided the chance to corroborate participant perspectives and revise inaccurate findings.

Another strategy used to determine the trustworthiness of study findings was triangulation, which helped improve the support of the findings of the study by comparing data from semistructured interviews and lesson plans (Marshall \& Rossman, 2015). Triangulation was a valuable method to establish confirmability and credibility of the research study's findings (Yin, 2014). Creswell (2013) and Merriam (2015) stated that triangulation enhances the integrity of the study through corroboration data from multiple sources, such as documents and interviews. In this study, the triangulation process included data from semistructured interviews and lesson plans. We analyzed the data and presented evidence to support the themes. Through strategies such as triangulation, researchers can bolster the credibility of a study.

\section{Findings}

The purpose of the study was to explore the instructional practices of elementary content teachers of ELLs and how those practices are perceived to align with improved ELL academic performance. The findings provide an understanding of participants' perceptions of working with ELLs and how they implemented instructional practices in mainstream classes.

\section{Findings-Research Question 1}

Two findings emerged. First, participants stated that they use cooperative learning strategies to promote English language acquisition among ELLs. Second, participants reported they use varied instructional strategies to meet ELL academic needs.

\section{Cooperative learning strategies}

The teachers implement cooperative learning strategies to promote English language acquisition among ELLs, which they believed allowed ELLs to feel validated as essential members of mainstream classrooms (Toppel, 2015). Alrayah (2018) examined the effectiveness of cooperative learning activities and found that a correlation existed between cooperative learning activities and improved ELL oral fluency. In addition, Zarifi and Taghavi (2016) stated that cooperative learning has a positive influence on ELL grammatical competence and contributes to a nurturing and collaborative environment for ELLs.

Participants believed that cooperative learning strategies are essential instructional practices used to teach ELLs in the classroom. One participant described how she employed cooperative learning strategies by "pairing an ELL student with low English proficiency with an ELL student who has high English proficiency." She said it "allowed the ELL student with low English proficiency to feel more confident in sharing in the classroom because this strategy encourages students to learn from each other.” Another participant shared that cooperative learning strategies, when used properly, encouraged "community building and relationships to help all students feel welcome and accepted and part of the classroom community.” One teacher 
commented on how the communication component with cooperative learning "helps all students but highlights the ELLs.” Also, another teacher added that,

I basically use the Kagan strategy that's like the turn and talk. It's really less work for me because they're talking to each other and kids learn best from each other. They pick up things from the teacher, but when we want mastery of a subject and things like that, they learn best from one another.

\section{Varied instructional strategies}

A second finding that emerged was teachers' use of varied instructional strategies to meet ELL needs. The interview data revealed the participants believed that varied instructional strategies provided the proper support to enhance student performance. The findings aligned with Ladson-Billings' (1994) CRP construct of academic success and cultural competence by implementing instructional practices that emphasize students' previous knowledge. The use of varied instructional practices is essential in meeting the academic needs of individual learners. Five of the nine participants used some form of varied instructional strategies that included small groups and multimodal approaches, such as graphic organizers, visuals, music, and gestures, and building on students' prior knowledge to help make content understandable for ELLs (Thompson, 2015). Most participants used small group instruction, cooperative learning, and visual learning and phonics worksheets in their lesson plans as a varied approach to learning. The findings align with Shaunessy-Dedrick et al. (2015), who explained that learning requires more than a one-size-fits-all approach. Castro (2015) also advocated the use of varied instructional practices with ELLs. Varied or differentiated instruction, according to Valiandes (2015), helps adapt instruction to meet the needs of ELLs. Finally, Ismajli and Imami-Morina (2018) agreed, indicating that differentiated teaching is a useful tool that helps teachers gain knowledge to support the individual needs of ELLs. Teachers can develop varied learning activities that address culturally and linguistically diverse learners.

\section{Findings-Research Question 2}

Two findings emerged from the data. First, participants stated that tapping into the expertise and cultural competence of English-as-a-second-language (ESOL) teachers created a necessity to increase collaboration opportunities with ESOL teachers. Second, participants stressed the importance of creating a welcoming and stress-free learning environment for ELLs.

\section{Collaboration with ESOL teachers}

The participants believed that encouraging collaboration between ESOL and classroom teachers can support regular classroom instruction by taking advantage of ESOL teachers' culturally competent expertise. This theme aligns with that of Babinski et al. (2018), who found that collaboration incorporating cultural competency in the classroom provides ESOL and elementary content teachers with the necessary skills to implement high-impact instructional methods. Also, Peercy Martin-Beltran et al. (2015) found that collaboration between ESOL specialists and elementary content teachers supports students by improving elementary content teachers' understanding of ELLs' cultural learning capabilities and requirements. All the participants agreed that collaborative activities provide the elementary content teacher and the ESOL teacher opportunities to combine their teaching methods.

One participant stated,

I think from my experience the ESOL teacher will also bring in an aide to spend one on one time with that child if they're really struggling and having problems. I am also reaching out to other teachers to get ideas about different curricula and different things to help my ELLs get the needed exposure.

Hong et al. (2019) stated that this improves the learning outcomes of ELLs. According to some participants, collaboration is especially beneficial in science and social studies, where the content-specific vocabulary can 
be more challenging. Cho et al. (2019) concurred and affirmed that students could achieve greater success when mainstream teachers and ESL teachers collaborate by sharing ideas on progress and incidences. The findings align with the criteria of Ladson-Billings' CRP (1995), which incorporates academic success and cultural competency into the classroom. The criteria state the importance of developing students academically and the need to nurture and support student cultural competence. Collaboration allows teachers to learn new and innovative teaching practices to develop academic achievement and can extend teachers' cultural competence that may have a positive effect on how their students learn.

\section{A welcoming learning environment}

A fourth finding that emerged from the participants' interviews was the importance of creating a welcoming and stress-free learning environment for ELLs. This, along with teachers becoming culturally competent, is in alignment with the constructs of CRP. Hogan-Chapman et al. (2017) examined ways to support teachers in obtaining cultural competence by engaging in simulation activities to create a welcoming learning environment. Hogan-Chapman et al. (2017) concluded that knowing and understanding students' home cultures were important in becoming a culturally responsive teacher. A stress-free and welcoming learning environment, according to Samalot-Rivera et al. (2018) and Ladson-Billings (1994), are classrooms where teachers take the time to learn about the different countries of origin for their ELLs. ELLs can also feel more welcomed and may be more willing to participate when instructional methods include culturally relevant music and games from the students' native countries (Cruz \& Petersen, 2011). Cervetti et al. (2015) and Ladson-Billings (1995) advocated that ELLs are apt to feel more comfortable practicing their English-speaking skills when teachers acknowledge and validate their students' native languages, creating a culturally inviting learning environment. Leveraging ELL native backgrounds can support the instructional strategies of elementary content teachers.

According to the perceptions of the participating teachers, a welcoming and stress-free learning environment makes ELLs more apt to focus on learning. One teacher commented that "first and foremost, when they come into my classroom, I make them feel welcome." She further stated that she's able to accomplish a welcoming environment,

by letting them know that whatever culture, whatever language they speak, all language or languages are also welcome. I thought my kids come in ashamed of their home language, and I try to sort of eliminate that thought process so then they'll be open to learning.

Another teacher stressed the importance of creating a learning environment in which ELLs feel accepted and welcome. She stated that,

foremost, we focus on community building and relationships. This helps all students feel welcome and accepted, and part of the classroom community. This is something I really focus on, especially in the beginning of the year, and then once that's established, I feel like the real learning can take place.

A third participant, when asked "what instructional practices are linked to improving the academic performance of ELLs?," stated that "a child learns best when a child feels welcome." She further stated that to create a welcoming environment, "I really have to be adept at the way they think and the pace at which they pick things up because they do have to work at a slower pace."

\section{Recommendations}

Based on the results of the data and existing literature, administrators might consider adopting recommendations that include district-level communication and collaboration and developing a diversity training program. The recommendations of the current study were consistent with Ladson-Billings' CRP 
theory, which stresses the importance of implementing intervention strategies for ethnically diverse students who struggle academically. The data confirmed the strong link between CRP and academically successful ELLs. Ladson-Billings stressed the importance of students achieving academic excellence and cultural competence aligning with the policy recommendations. CRP theory provides the basis to understanding the many dynamics that must be considered when designing effective instructional practices to meet the learning needs of ELLs.

\section{District-Level Communication and Collaboration}

The first recommendation based on the findings of this study is to implement strategies that improve collaboration between elementary content and ESOL teachers through district-level communication and interaction. Collaboration with ESOL teachers plays an important role when determining what practices and programs can assist ELLs who are struggling in mainstream classes. A thriving learning community, stated Ladson-Billings (1994), is characterized by cooperation, collaboration, and student learning for all. Most of the participants believed that implementing collaboration with ESOL teachers was significant and beneficial for increasing the academic performance of ELLs in mainstream classrooms. However, when asked whether they face any challenges having ELLs in their class, Participants 2, 3, 4, 7, and 9 stated that they struggled because their ELLs are pulled out of class by ESOL teachers. Although elementary content and ESOL teachers collaborated to support the learning needs of ELLs, factors such as inadequate planning time and insufficient professional training hindered them from consistently employing collaboration techniques in mainstream classrooms. Even participants who thought that increased collaboration was helpful still thought they had to work a little harder to manage their classrooms.

\section{Creating a Diversity Training Program}

The second recommendation based on this study is to implement a diversity training program to create a stress-free and welcome learning environment for ELLs. Consistent with Ladson-Billings' theory of CRP, the development of a diversity training program will provide elementary content teachers the cultural competency to better understand and communicate with their ELL students. Cultural competence, commented LadsonBillings (1995), no matter the ethnic background, should be part of the classroom experience for students to achieve academic success. Completing a diversity training program, according to Schwartz (2019), will allow teachers to better communicate with students and parents of culturally and linguistically diverse backgrounds. Practical diversity education courses provide participants an opportunity to look at their own cultural bias as it relates to their ethnically diverse classrooms (Cardona et al., 2018). Teachers are better able to understand the perspectives of culturally and linguistically diverse students and approach learning from their viewpoint when a healthy level of cultural competence is achieved.

\section{Importance to Stakeholders in a Larger Context}

Although a policy paper was developed in the context of a specific school district, other stakeholders may benefit from the project. The study may contribute to positive social change by providing researchers, institutions, and school districts with a better understanding of the instructional practices of content elementary teachers with ELLs. Equipping elementary content teachers with effective instructional methods helps support the learning needs of ELLs (Bautista, 2014). A better knowledge of instructional methods and their perceived linkage to the improved academic performance of ELLs may help prepare elementary content teachers to teach ELLs (Feiman-Neimser, 2018). The findings and recommendations from the study may be transferable. To ensure transferability, we obtained supportive documentation, vivid details, detailed, thick descriptions, and verbatim quotes from the participants to describe the findings. According to Merriam (2009), when researchers provide detailed explanations, the results become more realistic and valuable. The resulting project deliverable from this study will generate a better understanding of what instructional practices elementary education teachers perceive to be aligned with improved ELL academic performance. 


\section{Project Implications}

The positive implications of the study and policy paper at the local community level include increased awareness of the instructional practices used by teachers with ELLs in their classrooms. Effective instructional models for ELLs can help them achieve academically and attain higher levels of English proficiency (Vogt \& Echevarria, 2015). Evans (2018) stated that effective instructional models for ELLs could be delivered through teacher education programs. The instructional models should have the goals of preparing elementary education teachers to become productive with ELLs. The social change implication includes the potential of providing researchers and administrators with a better understanding of instructional practices, which will inform academic improvement efforts for ELLs.

\section{Implications, Applications, and Directions for Future Research}

This study provides findings regarding the instructional practices of elementary content teachers of ELLs and how those practices are perceived to align with improved ELL academic performance. The data collected indicated that participants had challenges related to collaborating with ESOL teachers. In this study, a policy recommendation, the benefits of improved collaboration between elementary content and ESOL teachers was suggested (Babinski et al., 2018). Therefore, the study findings and proposed policy recommendation paper can promote positive social change and provide insights into how local districts can incorporate collaboration between parties connected with improving ELL learning. Although this study provided thoughtful insights from elementary content teachers, recommendations for further research include the need to study the instructional practices of elementary content teachers through the lens of ESOL teachers (Hong et al., 2019). The deliverable, the policy paper, can be circulated to the district's leadership team. If the group accepts it, the strategies can be implemented in classrooms in the next school year. The advent of proper professional development may open avenues for those who struggle with English proficiency.

\section{Conclusion}

The problem addressed in this study is a need to explore the instructional practices of elementary content teachers of ELLs and how those practices are perceived by the teachers to be aligned with improved ELL academic performance. The policy recommendations were constructed through the lens of the study's conceptual framework, CRP. The data collected indicated that participants had challenges related to collaborating with ESOL teachers and stressed the importance of creating a welcoming and stress-free learning environment for ELLs. The findings were addressed through policy recommendations that call for building time into the school year for district-level communication and collaboration and creating a diversity training program. If district stakeholders adopt the implementation of the policy recommendations, this process can benefit ELLs at district elementary schools with a strategy to improve instructional practices of elementary content teachers. 


\section{References}

Alrayah, H. (2018). The effectiveness of cooperative learning activities in enhancing EFL learners' fluency. English Language Teaching, 11(4), 21-31. https://10.5539/elt.v11n4p21

Babinski, L. M., Amendum, S. J., Knotek, S. E., Sanchez, M., \& Malone, P. (2018). Improving young English learners' language and literacy skills through teacher professional development: A randomized, controlled trial. Grantee Submission, American Educational Research Journal, 55(1), 117-143. https://doi.org/10.3102/o002831217732335

Barragan, B., Castilla-Earls, A., Martinez-Nieto, L., Restrepo, M. A., \& Gray, S. (2018). Performance of lowincome dual language learners attending English-only schools on the clinical evaluation of language fundamentals. Language, Speech \& Hearing Services in Schools, 49(4), 292-305. https://doi.org/10.1044/2017

Bautista, N. (2014). LEVELING up: Addressing ELLs' language proficiencies and cognitive abilities in science classrooms. The Science Teacher, 81(4), 32-37. https://www.jstor.org/stable/i40151274

Caelli, K., Ray, L., \& Mill, J. (2003). 'Clear as Mud': Toward greater clarity in generic qualitative research. International Journal of Qualitative Methods 2(2), 1-13. https://doi.org/10.1177/160940690300200201

Cardona, M. C., Tichá, R., \& Abery, B. (2018). Education for diversity in initial teacher preparation programmes: A comparative international study. Journal of E-Learning \& Knowledge Society, 14(2), 79-95. https://doi.org/10.20368/1971-8829/1499

Carnoy, M., \& García, E. (2017, January 12). Five key trends in U.S. student performance. Progress by blacks and Hispanics, the takeoff of Asians, the stall of non-English speakers, the persistence of socioeconomic gaps, and the damaging effect of highly segregated schools. Economic Policy Institute.

Castro, E. (2015). Helping English language learners succeed in school. Education Digest, 8o(7), 44-47.

Castro-Olivo, S., Preciado, J., Le, L., Marciante, M., \& Garcia, M. (2018). The effects of culturally adapted version of First Steps to Success for Latino English language learners: Preliminary pilot study. Psychology in the Schools, 55(1), 36-49. https://doi.org/10.1002/pits.22092

Cervetti, G. N., Kulikowich, J. M., \& Bravo, M. A. (2015). The effects of educative curriculum materials on teachers' use of instructional stress for English language learners in science and on student learning. Contemporary Educational Psychology, 4O, 86-98. https://doi.org/10.1016/j.cedpsych.2014.10.005

Cho, H., Wang, X. C., \& Christ, T. (2019). Social-emotional learning of refugee English language learners in early elementary grades: Teachers' perspectives. Journal of Research in Childhood Education, 33(1), 40-55. https://doi.org/10.1080/02568543.2018.1531449

Cho, J. Y., \& Lee, E.-H. (2014). Reducing confusion about grounded theory and qualitative content analysis: Similarities and differences. The Qualitative Report, 19(32), 1-20. https://nsuworks.nova.edu/tqr/vol19/iss32/2

Choy, D., Wong, A. F. L., Lim, K. M., \& Chong, S. (2013). Beginning teachers' perceptions of their pedagogical knowledge and skills in teaching: A three year study. Australian Journal of Teacher Education, 38(5), 68-79. https://doi.org/10.14221/ajte.2013v38n5.6

Clark-Goff, K., \& Eslami, Z. (2016). Exploring change in preservice teachers' beliefs about English language learning and teaching. Iranian Journal of Language Teaching Research, 4(3), 21-26. http://ijltr.urmia.ac.ir/article_20352.html

Creswell, J. W. (2013). Qualitative inquiry \& research design: Choosing among five approaches (3rd ed.). Sage.

Creswell, J. W., \& Creswell, J. D. (2014). Research design: Qualitative, quantitative, and mixed methods approaches (5th ed.). Sage. 
Cruz, L. M., \& Petersen, S. C. (2011). Teaching diverse students: How to avoid marginalizing difference. Journal of Physical Education, Recreation \& Dance, 82(6), 21-28. https://doi.org/10.1080/07303084.2011.10598640

Davis, D. M., \& McCarther, S. M. (2015). Following the drinking gourd: Culturally relevant pedagogy and curriculum development through the arts. The Educational Forum, 79(1), 68-80. https://doi.org/10.1080/00131725.2014.971991

de Araujo, Z. (2017). Connections between secondary mathematics teachers' beliefs and their selection of tasks for English language learners. Curriculum Inquiry, 47(4), 363-389. https://doi.org//10.1080/03626784.2017.1368351

DeCapua, A. (2016). Reaching students with limited or interrupted formal education through culturally responsive teaching. Language and Linguistics Compass, 1O(5), 225-237. https://doi.org/10.1111/lnc3.12183

DeCapua, A., \& Marshall, H. W. (2015). Reframing the conversation about students with limited or interrupted formal education: From achievement gap to cultural dissonance. NASSP Bulletin, 99(4), 356-370. https://doi.org/10.1177/0192636515620662

Diaz, A., Cochran, K., \& Karlin, N. (2016). The influence of teacher power on English language learners' selfperceptions of learner empowerment. College Teaching, 64(4), 158-167. https://doi.org/10.1080/87567555.2015.1126801

Dong, Y. R. (2017). Tapping into English language learners' (ELLs') prior knowledge in social studies instruction. Social Studies, 108(4), 143-151. https://doi.org/10.1080/o0377996.2017.1342161

Evans, L. M. (2018). A case study examination of exemplary literacy teaching in a cross-linguistic, crosscultural learning environment. Literacy Research and Instruction, 57(4), 330-350. https://doi.org/10.1080/19388071.2018.1482033

Feiman-Neimser, S. (2018). What does research tell us about educating mainstream teachers to work with ELLs? The Educational Forum, 82(2), 227-234. https://doi.org/10.1080/00131725.2018.1420872

Gay, G. (2013). Teaching to and through cultural diversity. Curriculum Inquiry, 43(1), 48-70. https://doi.org/10.1111/curi.12002

Glesne, C. (2011). Becoming qualitative researchers: An introduction. Pearson Education.

Gomez, M. N., \& Diarrassouba, N. (2014). What do teachers need to support English learners? English Language Teaching, 7(5), 89-101. https://doi.org/10.5539/elt.v7n5p89

Grasparil, T. A., \& Hernandez, D. A. (2015). Predictors of Latino English learners' reading comprehension proficiency. Journal of Educational Research and Practice, 5(1), 35-57. https://doi.org/10.5590/JERAP.2015.05.1.03

Hatch, J. A. (2002). Doing qualitative research in education settings. State University of New York Press.

Hogan-Chapman, A., Lewis, B., Cooper, R., Howse, T., \& Warren, L. (2017). Using culturally responsive simulation activities to prepare teachers. National Teacher Education Journal, 10(1), 67-74.

Hong, H., Keith, K., \& Moran, R. R. (2019). Reflection on actions: Probing into English language art teachers' personal and professional experiences with English language learners. TESL-EJ, 22(4), 1-16. http://tesl-ej.org/pdf/ej88/a2.pdf

Ismajli, H., \& Imami-Morina, I. (2018). Differentiated instruction: Understanding and applying interactive strategies to meet the needs of all students. International Journal of Instruction, 11(3), 207-218. https://doi.org/10.12973/iji.2018.11315a

Jaffe, A. (2016). Social studies pedagogy for Latino/a newcomer youth: Toward a theory of culturally and 
linguistically relevant citizenship education. Theory \& Research in Social Education, 44(2), 147-183. https://doi.org/10.1080/o0933104.2016.1171184

Kim, W. G. (2017). Long-term English language learners' educational experiences in the context of high-stakes accountability. Teachers College Record, 119(9), 1-32.

Kvale, S. (2007). Conducting an interview. In Doing interviews (pp. 52-67). Sage. http://doi.org/10.4135/9781849208963

Ladson-Billings, G. (1994). The dreamkeepers: Successful teachers of African American children. Jossey-Bass.

Ladson-Billings, G. (1995). But that's just good teaching! The case for culturally relevant pedagogy. Theory Into Practice, 34(3), 159-165. https://doi.org/10.1080/00405849509543675

Ladson-Billings, G. (2006). Yes, but how do we do it? Practicing culturally relevant pedagogy. In J. Landsman \& C. W. Lewis (Eds.). White teachers/diverse classrooms: Creating inclusive schools, building on students' diversity, and providing true educational equity (pp. 29-42). Stylus Publishers.

Lodico, M., Spaulding, D., \& Voegtle, K. (2010). Methods in educational research: From theory to practice. John Wiley \& Sons.

Lopez, C. J., \& Mason, E. C. M. (2017). School counselors as curricular leaders: A content analysis of ASCA lesson plans. American School Counseling, 21(1b). https://doi.org/10.1177/2156759X18773277

Marshall, C., \& Rossman, G. B. (2014). Designing qualitative research (6th ed.). Sage.

Merriam, S. B. (2009). Qualitative research in practice: Examples for discussion and analysis. Jossey-Bass.

Merriam, S. B. (2015). Qualitative research: A guide to design and implementation (4th ed.). John Wiley \& Sons.

Murphy, A. F., \& Torff, B. (2019). Teachers' beliefs about rigor of curriculum for English language learners. The Educational Forum, 83, 90-101. https://doi.org/10.1080/00131725.2018.1505991

National Assessment of Educational Progress. (2019). The nation's report card. http://nationsreportcard.gov/

O'Brien, L. M., \& Leighton, C. M. (2015). Use of increasingly complex text to advance ELs' knowledge and academic language. Literacy Research: Theory, Method, and Practice, 64(1), 169-192. https://doi.org/10.1177/2381336915617579

Pappamihiel, N. E., \& Lynn, C. A. (2016). Adaptations for English language learners: Differentiating between linguistic and instructional accommodations. TESL-EJ, 2O(3), 1-13. https://files.eric.ed.gov/fulltext/EJ1122806.pdf

Peercy, M. M., Martin-Beltrán, M., Silverman, R. D., \& Nunn, S. J. (2015). “Can I ask a question?” ESOL and mainstream teachers engaging in distributed and distributive learning to support English language learners' text comprehension. Teacher Education Quarterly, 42(4), 33-58. https://files.eric.ed.gov/fulltext/EJ1090809.pdf (ed.gov)

Powell, R., Cantrell, S. C., Malo-Juvera, V., \& Correll, P. (2016). Operationalizing culturally responsive instruction: Preliminary findings of CRIOP research. Teachers College Record, 118(1), 1-46.

Ragoonaden, K., \& Mueller, L. (2017). Culturally responsive pedagogy: Indigenizing curriculum. Canadian Journal of Higher Education, 47(2), 22-46.

Samalot-Rivera, A., Treadwell, S. M., \& Sato, T. (2018). Instructional strategies to consider when teaching Hispanic English-language learners in physical education. Strategies: A Journal for Physical and Sport Educators, 31(2), 26-30. https://doi.org/10.1080/08924562.2017.1418691

Samuels, A. (2018). Exploring culturally responsive pedagogy: Teachers' perspectives on fostering equitable and inclusive classrooms. SRATE Journal, 27(1), 22-30. https://files.eric.ed.gov/fulltext/EJ1166706.pd f (ed.gov) 
Schwartz, S. (2019). The power of facing our unconscious bias. Education Week, 38(33), 10-16. http://ew.edweek.org/nxtbooks/epe/ew_05152019/index.php?startid=11

Shaunessy-Dedrick, E., Evans, L., Ferron, J., \& Lindo, M. (2015). Effects of differentiated reading on elementary students' reading comprehension and attitudes toward reading. Gifted Child Quarterly, 59(2), 91-107. https://doi.org/10.1177/0016986214568718

Thompson, J. D. (2015). Towards cultural responsiveness in music instruction with black detained youth: An analytic autoethnography. Music Education Research, 17(4), 421-436. https://doi.org/10.1080/14613808.2014.930117

Toppel, K. (2015). Enhancing core reading programs with culturally responsive practices. The Reading Teacher, 68(7), 552-559. https://doi.org/10.1002/trtr.1348

Turkan, S., \& Burzick, H. M. (2016). Complexities and issues to consider in the evaluation of content teacher of English language learners. Urban Education, 51(2), 221-248. https://doi.org/10.1177/0042085914543111

U.S. Department of Education. (2009). Race to the top. https://www2.ed.gov/programs/racetothetop/factsheet.html

U.S. Department of Education. (2015). Every student succeeds act (ESSA). https://www.ed.gov/essa

U.S. Department of Education. (2019). National center for educational statistics. https://nces.ed.gov/nationsreportcard/studies/gaps/

Valiandes, S. (2015). Evaluating the impact of differentiated instruction on literacy and reading in mixed ability classrooms: Quality and equity dimensions of education effectiveness. Studies in Educational Evaluation, 45, 17-26. https://doi.org/10.1016/j.stueduc.2015.02.005

Virginia Department of Education. (2018). Standards of learning. http://www.doe.virginia.gov/testing/sol/standards_docs/english/index.shtml

Vogt, M., \& Echevarria, J. (2015). Reaching English learners: Aligning the ELA/ELD framework with SIOP. The California Reader, 49(1), 23-33. https://readinghalloffame.org/sites/siop_ela_eld_correlation_article_oct._15.pdf

Vygotsky, L. S. (1978). Mind in society. The development of higher psychological processes (M. Cole, V. JohnSteiner, S. Scribner, \& E. Souberman, Eds. \& Trans.). Harvard University Press.

Yin, R. K. (2014). Case study research: Design and methods (5th ed.). Sage.

Zarifi, A., \& Taghavi, A. (2016). The impact of cooperative learning on grammar learning among Iranian intermediate EFL learners. Theory \& Practice in Language Studies, 6(7), 1429-1436. http://dx.doi.org/10.17507/tpls.0607.14

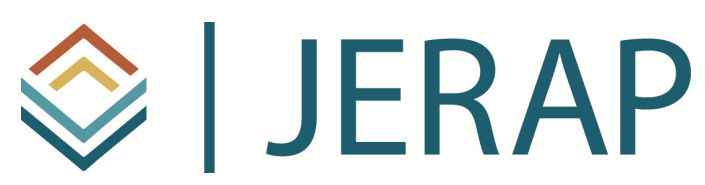

The Journal of Educational Research and Practice is a peerreviewed journal that provides a forum for studies and dialogue about developments and change in the field of education and learning. The journal includes research and related content that examine current relevant educational issues and processes. The aim is to provide readers with knowledge and with strategies to use that knowledge in educational or learning environments. JERAP focuses on education at all levels and in any setting, and includes peer-reviewed research reports, commentaries, book reviews, interviews of prominent individuals, and reports about educational practice. The journal is sponsored by The Richard W. Riley College of Education and Leadership at Walden University, and publication in JERAP is always free to authors and readers. 